\title{
The Curriculum Of Practice: A Conceptual Framework For Speech-Language Therapy and Audiology Practice With A Black African First Language Clientele
}

\author{
${ }^{1}$ Department of Speech \& Hearing Therapy \\ ${ }^{2}$ Department of Applied Curriculum Studies \\ University of Durban-Westville
}

Mershen Pillay ${ }^{1}$, Harsha Kathard ${ }^{1} \&$ Michael A. Samuel ${ }^{2}$

\begin{abstract}
This paper discusses the use of a conceptual framework (i.e., the curriculum of practice) to guide the transformation of professional practice toward equitable service provision, rooted in a research finding that South African Speech-Language Therapy \& Audiology has a favourable service bias toward White English / Afrikaans first language speakers (Pillay, 1997b). Three perspectives of practice are discussed, i.e., the official, espoused and actual perspectives. Also, the various elements of practice are reviewed, and include clinical practice activities, resources and their utilization, professional education curricular and professional policies. It is asserted that re-constructing the profession's knowledge base in a presently (1996-) transforming South Africa, mostly requires the use of a critical (versus, for e.g., a scientific) paradigm.
\end{abstract}

\section{OPSOMMING}

In hierfdie artikel word die gebruik van 'n konseptuele raamwerk(d.i. die praktykskurrikulum) bespreek om die transformasie van die professionele praktyk in werking te stel ten opsigte van regverdige dienslewering gegrond op navorsingsbevindinge dat die vakgebied van Spraak-Taalterapie en Oudiologie in die Suid-Afrikaanse konteks gekenmerk word deur' $n$ gunstige beroepsinslagjeens Blanke Engels- /Afrikaans-eerstetaalaprekers( Pillay, 1997). Drie praktyksperspektiewe word bespreek, naamlik die offisiële, bepleite en aktuele perspektiewe. Die verskillende praktykelemente word ook bespreek en sluit kliniese praktykaktiwiteite, hulpbronne en aanwending daarvan, professionele opleidingskurrikulums en professionele beleid in. Daar word aangevoer dat die belangrikste vereiste vir die rekonstruering van die beroep se kennisbasis in Suid-Afrika wat tans( 1996-) in 'n transformasie proses is, die gebruik van 'n kritiese (versus bv. 'n wetenskaplike) paradigma is.

KEY.WORDS: speech-language therapy and audiology practice; knowledge construction, critical paradigm, Black African first language speakers, curriculum of practice.

\section{INTRODUCTION}

The conceptual framework described in this paper is based on research conducted in 1996 (Pillay, 1997a \& $1997 \mathrm{~b})$, which focused on developing an understanding of the profession's practice with a'Black African first language speaking clientele. The use of this framework revealed that Speech-Language Therapy and Audiology is biased toward providing a better quality service to a White, English and Afrikaans first language speaking population, while concurrently providing a poorer service to a Black African first language speaking clientele (Pillay, 1996). Given the apartheid/racist context of its development, Speech-Language Therapy and Audiology services may hardly be understood otherwise. Arriving at an understanding of how the profession, or rather the people within it, have actually delivered their services within a racist/ apartheid framework; involved the use of a critical conceptual framework, which is promoted in this paper.

Why is it important to present such a framework? Primarily, this framework is intended to present a view on professional practice and to develop a common understand- ing of concepts associated with terms used within this framework. Many may find research results like that which claim that the profession's use of science has contributed towards its service bias, a ludicrous comment (Pillay, 1997). How could something like the impressive, rigourous and objective scientific method ever contribute toward maintaining a racist service? It is hoped that professionals use the curriculum of practice to position themselves in relation to concepts, such as that in the above example.

Speech-Language Therapy and Audiology has to provide an equitable service for Black African first language speaking clients given national political imperatives. Firstly, however, the focal term Black African first language speakers requires clarification: Black African first language speaker is a reference to the primary use of an indigenous language i.e., a country's native language (Language Plan Action Group, 1996) by Black South Africans who are themselves indigenous to this country, and whose ancestors'birthplace is pre-colonial Africa (Mesthrie, 1995). In other words, this refers to the Nguni class (i.e, isiZulu, isiXhosa, isiNdbele and SiSwati) and the Sotho class (i.e, Sepedi, Sesotho, and Setswana) of African languages 
which, according to the South African Constitution (1996) are considered as official languages. In South Africa people who speak an African first language are usually members of the apartheid racial classification referred to as Black, viz., the term Black African first language speakers.

For the profession of Speech-language Therapy and Audiology, language embedded within the broad framework of communication, is the critical focus of its work. It is therefore an important construct to consider given that language and culture (for example, the African language and the African culture) are closely intertwined, and that the nature and management of communication disorders must be viewed via a cultural perspective (Taylor \& Clark, 1994). If we view practice within generic concepts of factors like culture and language as opposed to specific concepts, for example, Black African and Zulu, we can then apply this framework of practice to any context. The application of the framework may, however, highlight different factors across specific contexts, for example, the issues related to Turkish first language speakers in London would be different from that of Afrikaans first language speakers in Durban.

The framework provided below is referred to as the curriculum of practice' and is a term that is catalytically defined within the next section. Figure 1 is a schematic representation of this framework which will now be discussed in detail.

\section{THE CURRICULUM OF PRACTICE: A CONCEP- TUAL FRAMEWORK.}

Could practice possibly be conceptualized in various ways? In other words, is there not only one way of looking at practice? The curriculum of practice has been generated in response to such questions. It is a term (coined for use by the author) that refers to the way in which we may view practice and its elements may be viewed. What is meant by this?

\subsection{PERSPECTIVES OF PRACTICE: AN ORGANI- SATIONAL FRAMEWORK.}

In order to review the perspectives of practice, let us assume a Speech-Language Therapist and Audiologist from another country visited South Africa, and that she/ he wished to know about how her/his South African counterparts provided a service to their clients, more especially their Black African first language clients. In order to investigate her/his interest regarding this clientele, she/he may obtain documents, for example official policies; and read them. This would provide her/him with an official understanding of the issue. Alternatives to finding out answers to her/his questions may be via direct, personal communication with the South African professionals themselves. Depending on where and with whom she/he is visiting she/he may ask the head professional practitioner of an institution, a university academic or practitioners themselves. These people would tell her/him about how they practice (or facilitate practice) with a Black African first language clientele, providing her/him with their espoused perspectives of what they do. One of these people might even invite her/him to visit their place of work, for a while, to see what actually happens. By observing such practice, she/he would gain an understanding of actual practice.
At the end of these various investigations the visitor should have some insight into Speech-Language Therapy and Audiology practice.

From the above illustration (which is, simplistically, similar to the qualitative research methodology used by Pillay, 1997a), we can see that the factors to consider within the curriculum of practice may be viewed from three perspectives (schematically placed on the border of Figure 1). These include the (2.1.1.) the official perspective, (2.1.2.) the espoused perspective, and (2.1.3.) the actual perspective. These perspectives provide a framework within which we may organise the various elements of practice, discussed below:

\subsubsection{The Official Perspective}

The official perspective refers to that perspective of practice which is documented in writing, and sanctioned by an authoritative body. Official perspectives (for example, those presented via policies) are produced via a rigorous process of being discussed and referred to as official. The Interim Medical and Dental Council of South Africa (INMDCSA) is a government-sanctioned organisation and its documents legally bind all registered practitioners to their policy statements, while the South African SpeechLanguage-Hearing Association's (SASLHA) policies (or guidelines) do not enjoy similar statutory status. In context of this paper, policies will be regarded as official by virtue of their origin from authoritative professional organisations. The issue of whether or not they are known to exist, i.e., effectively communicated (Hewton, 1988) to practitioners may also be important to consider within the official perspective.

\subsubsection{The Espoused Perspective}

The espoused perspective consists of statements, mediated in the verbal or written mode, which refer to practice

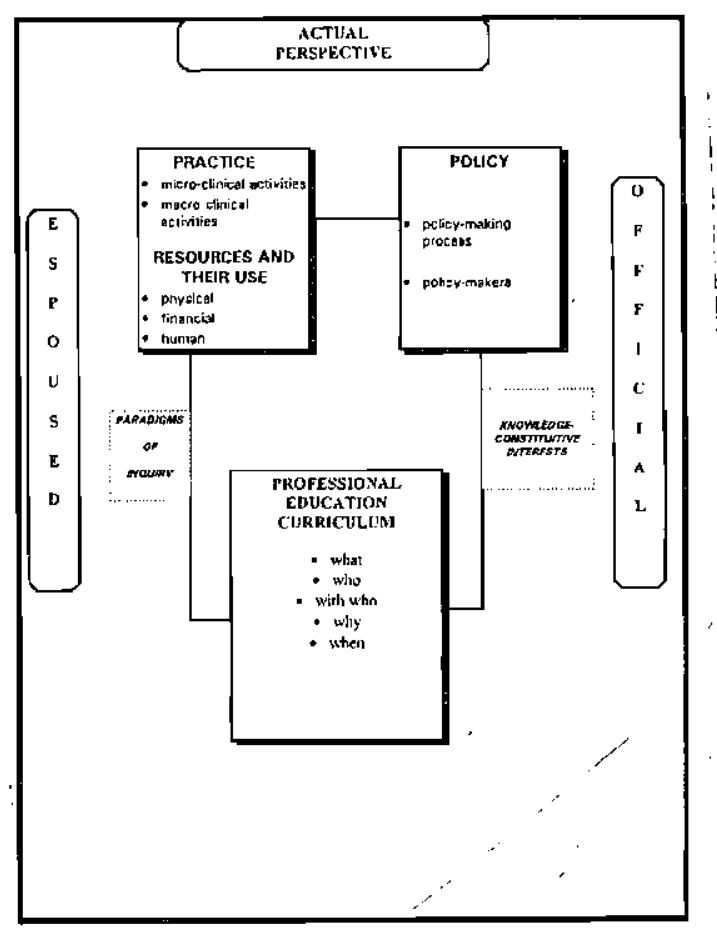

Figure 1: The curriculum of practice: A schematic diagram of the conceptual framework. 
as it happens. Such statements do not have official status due to the lack of the process involved in making official the concepts associated with practice. In other words, it is what practitioners/professional educators claim that they actually do. Examples of the written espoused perspective may be the sophisticated form of conference papers, journal articles; or the informal statements contained within various documents, for example, memos, client records, etc. This perspective may be understood within the professional education sector (i.e., from professional educators) and within the service sector (i.e., which include practitioners and professional managers).

\subsubsection{The Actual Perspective}

What actually happens then, is viewed as another perspective via which the curriculum of practice may be interpreted. Therefore, practice as it actually occurs in the work place (or reality site) is investigated as an actual perspective. Statements regarding this perspective may be generated via observations of the actual act of practice within the practice site. The practice site refers to the physical context in which practice (as performed by a practitioner) occurs. It includes the people involved in the process of practice, the resources (or equipment) utilised, etc.

With these perspectives in mind, what are the specific aspects that we may consider when viewing practice? The following discussion reviews the elements of practice to consider within the general organisational format provided above.

\subsection{THE ELEMENTS OF PRACTICE.}

In considering the elements of practice, (2.2.1.) practice activities, $(2.2 .2$.) resources and their utilisation, (2.2.3.) professional education curriculum, and (2.2.4.) professional policy are reviewed as part of the curriculum of practice:

\subsection{1, Practice Activities}

One may refer to practice activities within individual or group work, and (with reference to Figure 1) refer to two broad types:

2.2.1.1. Micro activities which are specific and distinctive to performing a professional function, comparable to what may be referred to within the concept of a core curriculum. In Speech-Language Therapy and Audiology one may consider the various clinical activities, i.e., the diagnostic and therapeutic aspects within the entire clinical management process, as collectively constituting these micro-activities.

2.2.1.2. Furthermore, one may consider the aspect of macro-activities, i.e., the activities linked to and impacting on the performance of the micro/core activities. Macro-activities for professional practice refers to macro-clinical activities which may include any activity directly related to the clinical management of the Black African first language client, for example clinical administration. Importantly, the policy making process and elements thereof, may' be an aspect within this category of macro-clinical activities. However, this element is given specific consideration within the curriculum of practice, as may be noted below.

An obvious element to consider within the curriculum of practice is the client's language and culture which should be a factor in determining the nature of the changes (if any) which is made to one's practice with such a clientele (Vaughn-Cooke, 1986). Furthermore, any reference to practice activities should account for the inherent status of the types of resources and their use. For purposes of this framework, this latter element of practice is highlighted:

\subsubsection{Resources And Their Use}

As may be noted in Figure 1, in order to achieve the above practice activities the practitioner may refer to three categories, including (2.2.2.1.) physical or material resources, for example the actual equipment used in the clinical and macro-clinical activities; (2.2.2.2.) human resources which refer to people involved in the clinical and macro clinical process, for example, the client's parents; and (2.2.2.3.) financial resources, i.e., finances that may be utilised for and/or during practice by the practitioners.

Ballantine, Ballantine \& Morgan (1982, in Bortz, 1992: 26) have correctly noted - in discussing the availability of assessment materials for the Black African first language speaking population - that “...we have limited tools available to perform the identification of speech and language problems, and those that do exist are inadequate".

This comment regarding clinical resources, in the form of tests and various therapeutic materials for use with the Black African first language client during clinical activities; is essential to consider within a framework intended to explain such practice. Also, it is known that the public sector services for Black African first language speakers are extremely under-resourced (Owen, 1995). Practitioners working in these contexts have high client case loads, and generally work under stressful conditions (Swindler $\&$ Ross, 1993). While this situation was designed and supported by the previous racist government's national budget scheme (Sinclair \& Place, 1991), the public practitioner is still faced with the present poor stock of all types of resources, and is an important factor to consider.

The above elements of practice activities and resource utilisation may be viewed from the point of what actually occurs, i.e., the actual perspective. Such professional practice may be perceived as constituting a set of actions or activities and may be defined as that which actually happens (Jansen, 1995). The notion of practice as that which actually happens must be considered (or re-considered) as consisting of more than just action. Practice is related to knowledge/theory, i.e., what one does is related to what one knows:

A practice... is not some kind of thoughtless behaviour which exists separately from theory and to which theory can be applied. Furthermore, all practices, like all observations, have theory embedded in them and this is just as true for the practice of theoretical pursuits as it is for those of practical pursuits like teaching [or speechlanguage therapy \& audiology]. [my insertion] (Carr \& Kemmis, 1986: 113)

The notion of practice as being a simple set of activities/actions is extended, to be contextualised within the 
theory in which such actions are always grounded. These aspects are schematically represented in Figure 1, and are the focus of the next section:

\subsubsection{The Concept Of Knowledge}

Habermas (according to Grundy, 1987; and Pusey, 1987) has stated that all human knowledge has fundamental cognitive interests. Grundy (1987) provides an understanding of what Habermas has meant by interests and then what he has meant by cognitive interests. She has explained Habermas' definition of interests as:

...the basic orientation of the human species is towards pleasure and that fundamentally what gives us pleasure is the creation of the conditions which will enable the species to reproduce itself. (Grundy, 1987: 8)

People's interests, which are usually self-satisfying, necessarily coincide with their values and beliefs (Grundy, 1987) and are rooted in a form of reasoning or rationality (Grundy, 1987), i.e., there is an addition of the cognitive dimension to Habermas' concept of human interests, i.e, knowledgeconstitutive interests (Habermas, in Pusey, 1987). This basic interest in self-preservation (guided by one's value orientation) has led people to compose knowledge in various ways. Grundy (1987) has asserted that knowledge-constitutive interests "...both shape what we consider to constitute knowledge and determine the categories by which we organise knowledge" (Grundy, 1987: 10).

Habermas (in Grundy, 1987) has proposed three knowledge-constitutive interests: the technical interest, the practical interest, and the emancipatory interest, summarised in notational form in Table 1. Firstly, the technical interest has a "...fundamental interest in controlling the environment through rule-following action based upon empirically grounded laws" (Grundy, 1987: 12). This interest is concerned with the ability to predict and therefore manipulate the environment giving rise to instrumental action which is judged in terms of its efficiency and effectiveness (Luckett, 1995).
Secondly, the practical interest is concerned with understanding through action. This interest has its roots in Habermas' (1972, cited in Pusey, 1987) theories of human speech and communication - based on assumptions of theorists like Freud (the well known psychoanalyst) and Hegel who, like Habermas, was a German philosopher (Pusey, 1987). The practical interest refers to the human being as a "language-using being ... using a form of knowledge to communicate with their fellows through the employment of mutually-understood symbols" (Kinchelhoe, 1991). Furthermore, it is concerned with the ability to make judgements about how to act morally and rationally within a specific social situation (Schubert, 1987). It results in subjective knowledge (as opposed to rule-following knowledge) which is usually produced through meaning-making interaction with one's environment (Grundy, 1987).

Thirdly, the emancipatory interest:

... goes beyond the technical interest of controlling objects in the environment and the practical interest of fostering intersubjective understanding. The emancipatory interest is concerned with a form of knowledge which leads to freedom from dominant forces and distorted communication.(Kinchelhoe, 1991: 70).

The emancipatory interest is concerned with autonomous social action as a result of "authentic, critical insights into the social construction of human society" (Grundy, 1987:19). Emancipation (or freedom) and self-knowledge are restricted by often unrecognised social and political conditions (Kinchelhoe, 1991)

Regarding, the notions of science, it is significant to note that Habermas (in Pusey, 1987) has viewed all the knowledge-constitutive interests as motivated by rational inquiry: A concept which is closely linked with what is commonly referred to as science. In fact, as Pusey (1987) has noted, Habermas promotes rational inquiry and is for science. However, Habermas promotes a different science, that which he refers to as scientism. Habermas (1972, in Pusey, 1987) has used the term scientism to promote "...science's beliefin itself: that is, the conviction that we can no

Table 1.: A summary of the main features of the three knowledge-constitutive interests.

\begin{tabular}{|l|l|l|}
\hline \{PRIVATE\} The Technical Interest & The Practical Interest & The Emancipatory Interest \\
\hline $\begin{array}{l}\text { aimed at controlling the } \\
\text { environment }\end{array}$ & $\begin{array}{l}\text { aimed at gaining understanding } \\
\text { through action }\end{array}$ & $\begin{array}{l}\text { concerned with autonomous } \\
\text { social action for transformation }\end{array}$ \\
\hline $\begin{array}{l}\text { uses rule-following action, } \\
\text { based on empirical laws }\end{array}$ & $\begin{array}{l}\text { human beings and their behaviour } \\
\text { are viewed within a communicative } \\
\text { model }\end{array}$ & $\begin{array}{l}\text { uses the concept of ideology- } \\
\text { critique/ critical insights }\end{array}$ \\
\hline based on ability to predict & $\begin{array}{l}\text { based on ability to make morally } \\
\text { and rationally oriented judgements } \\
\text { in specific social situations }\end{array}$ & $\begin{array}{l}\text { emphasises the recognition and } \\
\text { freedom from dominant social } \\
\text { and political forces }\end{array}$ \\
\hline $\begin{array}{l}\text { desires to manipulate the } \\
\text { environment }\end{array}$ & $\begin{array}{l}\text { results in subjective knowledge } \\
\text { relies on intersubjective } \\
\text { understanding }\end{array}$ \\
\hline $\begin{array}{l}\text { focuses on instrumental action } \\
\text { and effectiveness }\end{array}$ & $\begin{array}{l}\text { knowledge is produced via } \\
\text { meaning-making with one's } \\
\text { environment. }\end{array}$ & $\begin{array}{l}\text { knowledge gained is intended } \\
\text { to be utilised for the freedom } \\
\text { from dominant forces and } \\
\text { distorted communication }\end{array}$ \\
\hline
\end{tabular}


longer understand science as one form of possible knowledge, but rather must identify knowledge with science" (Pusey, 1987: 20). In addition, he has claimed that "...science can only be comprehended epistemologically, which means as one category of possible knowledge, as long as knowledge is not equated with....scientistic self-understanding of the actual business of [scientific] research" (Pusey, 1987: 20).

Habermas' reference to science as only being understood epistemologically is significant. This assumption is based on the nature of the three knowledge-constitutive interests given that they are different from each other. It may be concluded that what one considers as basic knowledge/ truth is dependent on one's value orientation, i.e., there is more than one version of truth (Guba \& Lincoln, 1994). Put another way: there is more than one story to be told, i.e., we construct knowledge according to the way we see the world. In this process of knowledge construction, the way we see the world is not only personally constructed, but related to paradigms of inquiry which is the focus of the next section:

\subsubsection{Paradigms and the construction of knowl- edge}

\section{Guba \& Lincoln (1994) have defined a paradigm as:}

a set of basic beliefs (or metaphysics) that deal with ultimates or first principles. It represents a worldview that defines for its holder, the nature of the "world", the individual's place in it, and the range of possible relationships to that world and its parts, as for example, cosmologies and theologies do. (Guba \& Lincoln, 1994: 107).

These paradigms are each governed by Habermas' theory of knowledge-constitutive interests. Historically, knowledge (for professional practice) has been guided by three paradigms (Hartman \& Warren, 1994). These three paradigms include the empirical-analytical paradigm, the hermeneutic-interpretive paradigm, and the critical paradigm. Carson's (1990) overview (quoted below) of the relationship between Habermas' knowledge-constitutive interests and these paradigms provides a basic definition of each paradigm. Furthermore, it sufficiently explains the relationship between knowledge-constitutive interests and paradigms of inquiry for purposes of this discussion.

... [Habermas'] three basic orientations...[are] governed by a particular interest. One is an orientation to material well-being, governed by a technical interest in acting on the world. This produces an empirical knowing in the form of facts and generalisations. A second orientation, towards communication, is governed by a practical interest in understanding others. The form of knowing that this produces is situational and interpretive, rather than generalisable and empirical. The third orientation is toward freedom and it is governed by an emancipatory interest in liberating persons from oppressive situations. This produces a critically reflective knowledge [my insertions and emphases] (Carson, 1990: 168).

While Habermas' theory of knowledge-constitutive knowledge relates to three types of paradigms, "... it is not at all clear what sort of and how many distinct and monolithic social scientific paradigms do really exist" (Smaling, 1992: 5). However, for this article the popular types of paradigms are discussed.

\subsection{The types of paradigms.}

As has been noted in Carson's (1990) quote above, the three main paradigms are the empirical-analytical, the

Table 2: A summary of the main features of the three paradigms of inquiry

\begin{tabular}{|c|c|c|c|}
\hline $\begin{array}{l}\text { Key Features } \\
\text { of Paradigms }\end{array}$ & $\begin{array}{l}\text { The Empirical- } \\
\text { Analytical Paradigm }\end{array}$ & $\begin{array}{l}\text { The Hermeneutic- } \\
\text { Interpretive Paradigm }\end{array}$ & The Critical Paradigm \\
\hline $\begin{array}{l}\text { Reality/ } \\
\text { Ontological } \\
\text { comment }\end{array}$ & $\begin{array}{l}\text { Reality: } \\
\text { - is apprehensible } \\
\text { - is driven by natural laws and } \\
\text { mechanisms (deterministic) } \\
\text { - may be reduced to manipula- } \\
\text { ble parts } \\
\text { - is objective }\end{array}$ & $\begin{array}{l}\text { Reality: } \\
\text { - is apprehensible, but multi- } \\
\text { ple realities exist. } \\
\text { - may change, as the reality } \\
\text { constructor (researcher) be- } \\
\text { comes more informed/sophis- } \\
\text { ticated }\end{array}$ & $\begin{array}{l}\text { Reality: } \\
\text { - is historically grounded } \\
\text { - shaped by social, political, } \\
\text { cultural, economic, ethnic } \\
\text { and gender views }\end{array}$ \\
\hline $\begin{array}{l}\text { Truth/ } \\
\text { Epistemological } \\
\text { comment }\end{array}$ & $\begin{array}{l}\text { Truth: } \\
\text { - exists outside of the re- } \\
\text { searcher, and may be } \\
\text { accessed via various objective } \\
\text { techniques }\end{array}$ & $\begin{array}{l}\text { Truth: } \\
- \text { is subjective } \\
- \text { may be obtained interac- } \\
\text { tively }\end{array}$ & $\begin{array}{l}\text { Truth: } \\
\text { - is value-mediated and } \\
\text { value-dependent } \\
\text { - is socially constructed via } \\
\text { the investigator and re- } \\
\text { spondents }\end{array}$ \\
\hline $\begin{array}{l}\text { Methodological } \\
\text { comment }\end{array}$ & $\begin{array}{l}\text { Methods used: } \\
\text { - Emphasise experiments } \\
\text { - can predict phenomena } \\
\text { - allow for testing hypotheses } \\
\text { - control for confounding con- } \\
\text { ditions }\end{array}$ & $\begin{array}{l}\text { Methods used: } \\
\text { - facilitate the creation of } \\
\text { knowledge via meaningful in- } \\
\text { teraction with the investiga- } \\
\text { tor and respondents }\end{array}$ & $\begin{array}{l}\text { Methods used: } \\
\text { - include dialogic/dialectical } \\
\text { techniques } \\
\text { - emphasise ideology critique }\end{array}$ \\
\hline
\end{tabular}


hermeneutic-interpretive, and the critical paradigm, which relate to the technical, practical and emancipatory interests, respectively. Guba and Lincoln's (1994) interrogative framework which highlights each paradigm's ontological, epistemological, and methodological orientation, may be used to explain each paradigm: The question relating to ontology is: "What is the form and nature of reality and, therefore, what is there that can be known about it?" (Guba \& Lincoln, 1994: 108). This question focuses on the paradigm's claims made about reality, while the epistemological question focuses on knowledge or truth. The epistemological question is: "What is the nature of the relationship between the knower or would-be knower and what can be known?" (Guba \& Lincoln, 1994: 108).

Finally, the manner in which research is performed, i.e., the methodology or the paradigm's mode of inquiry is evaluated via the question: "How can the inquirer (wouldbe knower) go about finding out whatever he or she believes can be known?" (Guba \& Lincoln, 1994: 108). Method/mode of inquiry is the key concept that this question seeks to address. These key questions/features of the paradigms of inquiry are summarised in Table 2 in order to enable greater clarity of the text in this section.

\subsection{Choosing the outfit to suit the occasion.}

Selecting which paradigm to rely on - possibly not exclusively so - during the profession's development is related to the issue of making a paradigmatic-pragmatic choice. Simply put, one needs to choose the outfit to suit the occasion. It is asserted that effecting critical change in the South African profession necessarily involves having to identify the fundamental paradigmatic values and beliefs underlying Speech-Language Therapy and Audiology. In order to achieve such a thing, the use of the critical paradigm of inquiry is best suited to this purpose. A brief discussion on the range of the commonly used research paradigms ensues in order to better contextualise the critical paradigm's features. However, the focus on this theoretical review will be on the critical paradigm itself.

Most attempts at gaining knowledge, seek to achieve an answer to the question: 'what is truth'? In doing so, it must be acknowledged that paradigms couch the way reality is viewed, i.e., they provide views of the world via different lenses. If this is the case then what story may one tell with a critical lens? What does this paradigm encourage?

"A critical perspective requires a historical perspective. We can forgive, but we should not forget" (Villanueva, 1993: 12). The critical paradigm may be described as encouraging a view on reality (via research) as being historically grounded. Reality is promoted as being shaped by social, political, cultural, economic, ethnic, and gender views, amongst others (Guba \& Lincoln, 1994). Therefore, if these factors shape reality then it follows that truth is mediated by the values which such things as constructs of gender or political views inculcate: Within the critical paradigm, truth is seen as value-dependent and value-mediated. More importantly truth is seen as being dually constructed by the investigator and the respondents and as such is socially contestable.

At this point it may be useful to digress slightly toward an understanding of the nature of paradigms, in order to better situate the critical paradigm. Generally, paradigms are founded on basic beliefs to be accepted "...simply on faith (however well argued). There is no way to establish their ultimate truthfulness" Guba \& Lincoln (1994: 107), as they are constructed by people with their personal beliefs.

Paradigms - even when ontologically, epistemologically and methodologically dissimilar - should not compete with each other (Guba \& Lincoln, 1994: 116), but ought to rely on persuasiveness and utility rather than proof in arguing their position (Guba \& Lincoln, 1994: 108). Therefore, while an empirical-analytical approach is useful for the speech-language therapist and audiologist to understand the anatomy of the middle-ear; auditory processing may be better investigated via the use of the hermeneutic-interpretive paradigm's methods. Importantly, an excessive use of one paradigm to understand all aspects of a profession/field's scope, may be inappropriate (Kinchelhoe, 1991). This singular use of a paradigm may be because it is pervasive (either explicitly/implicitly) in the process of knowledge construction by being all owed to dominate a particular profession, for e.g., like that of Speech-Language Therapy and Audiology and how it researches/re-looks at its focal field of inquiry.

The implicit domination of a paradigm refers to a form of hegemony or ideological domination (Villanueva, 1993). Importantly, the empirical -analytical paradigm has, since its origins, dominated the production of knowledge in hegemonic form. Hegemony is an important factor to note, not only for understanding ideological domination with regard to paradigms of inquiry, but also in understanding how prejudice, relative to class, gender and/or race are hegemonically maintained. The tenets of the empiricalanalytic paradigm (refer to Table 2) have promoted the type of research that for example, has fuelled racism (Villanueva, 1993) by proffering racist research as neutral and objective. The most myth-destroying comment that can be made about the concept of knowledge is that: knowledge is never neutral - it is socially constructed, value-laden, subjective and provisional (Luckett, 1995).

The myth that knowledge can be objective, neutral, and value-free has been promoted primarily by the empiricalanalytic paradigm, and must be recognised as being only one way of looking at the world. A point worth noting is that the use of the empirical-analytical and hermeneutic paradigms are not suitable to transform a profession ('Carr \& Kemmis, 1986). Presently, Speech-Language Therapy and Audiology is guided by the political imperative to transform its service and professional education to better serve a Black African first language clientele. Therefore, if transformation is on the profession's agenda then the critical paradigm seems most appropriate for this function. An understanding of what paradigm has influenced the practice of a profession, will reveal information about what such practice values/views as important. It may, for e.g., indicate whose values these are or whose values are being served via particular practice, as one may discover, that South African White English/Afrikaans first language speakers enjoy the benefits of Speech-Language Therapy and Audiology's practice.

A profession's hegemonic promotion of a paradigm, for e.g., the empirical-analytical paradigm; and promotion of social values, for e.g., White (race) and English (languageculture) predominantly relies on the use of various structures and mechanisms. These may include, for e.g., the process of student selection, professional educational courses and syllabi, the profession's standards of practices, and its research and publications (Pillay, 1997a). 
Such values and beliefs are not only promoted via actual practice. One may also understand practice with regard to how it is promoted or facilitated via the professional policies (via written 'policy statements') for practice or via the professional education curriculum. Regarding the latter two viewpoints, there are additional clements related to each that require further consideration. Let us turn to the aspects associated with professional education curriculum for an overview of further elements to consider within this element of the curriculum of practice.

\subsubsection{Professional education curriculum}

In considering the professional education curriculum development aspects of practice, the practice activities and resource utilisation elements of practice - as facilitated via the professional education curriculum, requires consideration. In Figure 1, this aspect is linked with practice given that the professional education curriculum facilitates such practice. Aron (1991), Schneider (1992), McKenzie (1992), Kathard \& Pillay (1993), Uys (1993), Jager (1994), Kathard (1994), Pillay (1994) and Pillay \& Kathard (1994) and Kathard (1996a \& 1996b) have highlighted both the need to investigate, and aspects to consider in the academic preparation of professionals for practice with a Black African first language clientele.

The previous discussion focused on how the construction of knowledge may occur within the practice dimension of a profession, like Speech-Language Therapy and Audiology. Similar paradigmatic processes have permeated the construction of professional education curricula (Schubert, 1987; Grundy, 1987; Luckett, 1995) so that professions, like Speech-Language Therapy and Audiology may promote their professional knowledge base. The term curriculum or professional education curriculum shall be understood by its broadest definition as the "...interlinked complex of who is taught, what is taught, how it is taught, who teaches, and within what context we teach" (Gerwel, 1991: 10). Therefore, what is taught (the syllabi), who teaches (the professional educators), how it is taught (the teaching and learning process), to whom teaching occurs (the learners), and the context (for example, the reality site of a community setting or the lecture theatre) of teaching are factors which are regarded as basic to the concept of curriculum.

Given that professional practice (e.g., of teaching, law, medicine or speech-language therapy and audiology) is being facilitated, the relationship between theory and practice has been differently promoted within each of these paradigms. It is the intention of this discussion to suggest that the empirical-analytical paradigm offers a rather limited and framed-in conception of the relationship between knowledge and action, theory and practice. Since its paradigmatic assumptions force it to dichotomise the relationship between the two constructs, it often leaves the practitioner in the field to mystify theory (Carr \& Kemmis, 1986). This also results in practitioners being unable to critique the underlying values and assumptions of this paradigm (Grundy, 1987). Practitioners often become unable to critique their own practice since they naturalise the axiomatic beliefs of the paradigm. Lincoln \& Guba (1985) argue that it is difficult for fish to understand what water is because they have lived all their lives in it.

The radical critique necessary to transform professional education curricula is offered within the critical paradigm which celebrates the reflexive and constructive interac- tion between theory and practice. Upon examining the nature of the relationship between theory and practice, one may discover myths associated with the theory-practice relationship. Significantly, there are three myths worth considering with such a discussion on practice. These three myths, generated by the influence of the empirical-analytical paradigm, are that (a) theory is non-practical and practice is non-theoretical; that (b) theorists and practitioners are totally separate; and that (c) the relationship between theory and practice is linear and hierarchical. A critical examination of these assumptions/myths of the theory-practice relationship may reveal that (a) knowledge and action are located within the same realm, i.e., theory is a statement of practice and practice is a statement of theory; (b) theorists and practitioners are functionally the same, working with the same problem, using methods which are similar, and which are essentially derived from shared beliefs and values; and (c) knowledge and practice are not linearly or hierarchically related, but reflexively and constructively interlinked (Grundy, 1987; Carr \& Kemmis, 1986).

The critical paradigm's perspective of the theory-practice relationship is deemed suitable as it incorporates and develops the dialectic/dialogic view of this complex relationship (Grundy, 1987) . Furthermore, it acknowledges the professional education's political milieu and its intention to transform; which are critical factors to account for in any attempt at understanding the profession's practice. In addition, it promotes the curriculum as a dynamic entity for facilitating practice during a dynamic period - such as that associated with the dynamism of social transformation. Therefore, the critical paradigm is selected as the preferred mode of inquiry from which to vicw practice.

A broad summary of what has been stated regarding the theory associated with practice so far is that, when one considers practice, one has to consider more than just the action or the set of activities. The resources and how they are utilised to achieve these activities are as important. Furthermore, the knowledge base of such practice as defined by the professional education curriculum that facilitates and reflects practice is also important to consider. This knowledge base has been explained with reference to knowledge-constitutive interests that govern paradigms of inquiry, as manifested in the curricula models used for professional education. With this in mind, let us now turn to the other significant aspect of practice, i.e., the policies relative to practice.

\subsubsection{Professional Policy}

This element is related to the perspective of practice as policy and is intended to add to the previous discussion on practice. Policy, like the professional education curriculum, may also be influenced by the three paradigms. In light of this factor, aspects of how the policy-making process occurs for professional practice, who the policy makers are, and (of course) what the policies reflect; deserve consideration. A definition of what is meant by policy is a necessary, yet difficult task to achieve, as numcrous differing definitions exist. However, Hewton's (1988) definition of policy may be used to guide one's conceptual understanding of it. He has defined policy as:

a set of interrelated decisions relating to a particular activity concerning the selection of goals and means of achieving them over a period of time (Hewton, 1988: 78) 
A policy, which may exist without being written, serves as a focusing device for the core task at hand; provides a form of organisational analysis (requiring the assessment and ordering of needs); is a direction finder (requiring a statement of aims), a co-ordinating mechanism (for bringing together disparate - yet related - activities); indicates the policy-maker's commitments; and is an instrument of communication for all the above. Also, it may serve as a framework of coping with change (Hewton, 1988). Furthermore, elements of policy as consisting of aims (including the assessment of needs), a rationale, a programme (including activities, costs and timing) and an evaluation, may be considered in a discussion of the concept of policy (Hewton, 1988).

While Hewton's definition of policy is useful for a general understanding of the concept, it may be regarded as not being different to technicist curriculum models. Therefore, Jansen's (1994) presentation of the conceptions of policy specific to curriculum (of education practice) are noteworthy. Jansen has reviewed four concepts of policy. The first concept of such policy refers to that which actually happens, where practice (activities) are taken as a starting point for policy reflections. This concept highlights the role of the practitioner in the policy-making process. A second concept relates curriculum policy as political symbolism, where attention is drawn to the political motivations which often drive particular policies. Thirdly, policy may also be conceived of as the specification of official intentions. This is when policies contain specific guidelines from the official policy makers, which the practitioner may follow. Finally, another concept of policy regards policy as containing broad guidelines for practice, providing practitioners with a general (as opposed to a specific) set of guidelines to utilise. Within each conception of practice, the role of the policy-maker is highlighted. Relative to this is the role of the practitioner, who may be perceived as a recipient of the policy or as an active contributor to the policy-making process.

These hermeneutic-interpretive oriented notions may be critiqued for their overemphasis on the process of who and how policies are developed, risking the actual transformation of policies in the process. The emphasis on the policy process itself may result in minimal attention being paid to what is actually done (Samoff, 1996), i.e., the extent of which practice has transformed via the policy process is a concern of the critically-oriented model. Nevertheless, the power of policies should never be underestimated (Jansen, 1995) and their role in the practice of any profession, for example Speech-Language Therapy and Audiology, should be given due consideration.

Therefore, the process of policy-making is important to consider when focusing of the practice of the profession where the intention is to transform practice. As such, one needs to consider more than the content/policy statements contained within these official documents. Present-day professional practice has highlighted the political importance - noted for consideration - (a) the identification and role of the policy-makers; and (b) the process of policy-making.

\subsubsection{The policy-making process}

This refers to the way in which policies for professional practice are devised, within the element of professional policy presented in the curriculum of practice. It is not peculiar to official policy statements regarding the proc- ess. It may include that which actually occurs in the practice site, and what is facilitated via the professional education curriculum.

\subsubsection{The identification and role of policy-makers}

Similarly, who generates policy must be considered with reference to how this actually occurs and how it is facilitated via the professional education curriculum in addition to what is stated in the policy documents regarding this issue.

\section{CONCLUSION}

If you're white/ you's alright/ if you're brown/ mmmm ... stick aroun'/ if you's black/git back, git back! (Anon, in Brindley, 1972).

This popular poem has been quoted to present, what may be seen as, the prevalent perspective on race (and associated factors) within the various sectors of South African health care, education, etc. As practitioners within the profession of Speech-Language Therapy and Audiology, we have to be able to critically reflect on how much of this perspective is promoted (implicitly or otherwise) by what we think about race (and what comes with being a colour in South Africa) and how we may translate such thoughts into all aspects of our lives - more especially in the way we work.

The belief that the critical paradigm is better suited for use by the profession during South Africa's great era of political transformation is promoted along with the suggestion to use appropriate, perhaps more qualitative methods of inquiry. In this regard, the interested reader is referred to an action plan which has provided recommendations to focus on the use of action research in the profession's pursuit to develop its practice (Pillay, 1997a \& 1997b). The curriculum of practice may aid Speech-Language Therapy and Audiology to reflect on where we have come from by critically de-constructing racist, apartheid values that underlie the profession's curriculum of practice. Significantly, this framework should also assist us to consciously define where we intend to go, so that we can re-construct ourselves and actually do respond to theicritical health care needs of South Africans within the present (1997-) moment of history-making.

\section{ACKNOWLEDGEMENTS}

Ruth Beecham, friend and ex-colleague at UD-W, whose Tofller-like mind provided the inspiration for this study. Melanie Adams (Speech-language Therapist, Camden \& Islington Community Health Trust, London,UK) for reviewing initial drafts of this paper.

\section{REFERENCE LIST}

Aron, M.L. (1991). Perspectives. South African Journal of Communication Disorders. 38, 3-11.

Anon, in D.J. Brindley (1972). The turning world.'Johannesburg: Juta \& Co. Ltd.

Ballantine, J., Ballantine, P.R.. \& Morgan, R. (1982). Auditory perceptual skills in Zulu school children: A preliminary normative investigation. In M.A. Bortz,(1992). Language abilities of 18-month old Zulu speakers. South African Journal of Communication Disorders. 39, 25-35. 
Carr, W. \& Kemmis, S. (1986). Becoming critical: Education, knowledge and action research. London: The Falmer Press.

arson, T. (1990). What kind of knowing is critical action Carson, Theory Into Practice, 3, 167-173.

Terwel, J. (1991). Intellectuals in a changing South Africa. David Webster Memorial Speech, University of the Witwatersrand, Johannesburg.

Gundy, S. (1987). Curriculum: Product or Praxis?. London: The Falmer Press.

Juba, Y.S. \& Lincoln, G.E. (1994). In E.G. Guba \& N.K. Denzin. Handbook of qualitative research. New York: McGraw-Hill.

tabermas, J. (1972 cited in M. Pusey (1987). Jurgen Habermas. England: Tavistock Publications Ltd.

Hartman, N. \& Warren, D. (1994). Perspectives on a framework for curriculum development created for use in the faculty of social science and humanities at the University of Cape Town. Proceeding of the South African Association for Academic Development Conference, University of Natal-Durban, Durban, KwaZulu-Natal.

Hewton, E. (1988). School focused staff development: Guidelines for policy makers. London: Falmer Press.

Jager, G.W. (1994). Community based education in speech pathology and audiology at the University of Durban-Westville in an under-served community. South African Journal of Communication Disorders, 41, 93-99.

Jansen, J. (1994). Standards and other myths. The transformation of universities in South Africa. Paper presented at the Academic Freedom Lecture, University of Natal-Pietermaritzburg, KwaZulu-Natal.

Jansen (1995). Pedagogy as policy. Keynote address to the South African Association of Research in Mathematics and Science Education Conference, University of Cape Town, Cape Town.

Kathard, H. (1994). Audiology and speech-language therapy: Developing practice and education. Paper presented at the South African Speech-Language-Hearing Association Conference, Durban, KwaZulu-Natal.

Kathard, H. (1996a). Curriculum transformation issues: Context and paradigms. Unpublished article.

Kathard, H. (1996b). The curriculum: Critical questions and practical outcomes: Department of Speech \& Hearing Therapy, University of Durban-Westville. Unpublished article.

Kathard, H. \& Pillay, M. (1993). Educational development and professional transformation: A case discussion. Paper presented at the South African Association of Academic Development Conference, University of the Western Cape, Cape Town.

Kinchelhoe, J.L. (1991). Teachers as researchers: Qualitative inquiry as a path to empowerment. London: The Falmer Press.

Language Plan Action Group (LANGTAG) (1996). Towards a national Language Plan for South Africa. Final Report of the Language Plan Action Groụp (LANGTAG), Ministry of arts, culture, science and technology, South Africa.

Lincoln, Y.S. \& Guba, E.G. (1985). Naturalistic inquiry. London: Sage.

Luckett, K. (1995). Towards a model of development for the University of Natal's curriculum reform programme. Academic Development, 1, (2), 125-141.

McCarthy, (1978). In S. Grundy (1987). Curriculum: Product or Praxis?. London: The Falmer Préss.

McKenzie, J.A. (1992). The provision of speech and hearing services in a rural district of South Africa. South African Journal of Communication Disorders, 39, 50-54.
Mesthrie, R. (Ed.) (1995). Language and social history: Studies in South African Linguistics. Cape Town, David Philip.

Owen, C.P. (1995). (Ed.) A policy for the development of a district health system for South Africa. Pretoria: Department of Health.

Pillay, M. (1994). Mentoring: A form of continuing education for Speech-Language Therapists \& Audiologists in South Africa. Paper presented at the Speech-Language-Hearing-Association, KwaZulu-Natal, Durban.

Pillay, M. (1997a). SASHLA bashing?!, Communiphon, South African Speech-Language-Hearing Association: University of Witwatersrand, Johannesburg.

Pillay, M. (1997b). Speech-Language Therapy \& Audiology: Practice with a Black African First Language Clientele. Unpublished Master's dissertation, University of DurbanWestville, Durban.

Pillay, M. \& Kathard, H. (1994). Student assessment: Issues of policy and practice in the health sciences. Paper presented at the conference of the South African Association for Academic Development, University of Natal-Durban, Durban, KwaZuluNatal.

Pusey, M. (1987). Jurgen Habermas. England: Tavistock Publications Ltd.

Rajah, D.S (1992). Paradigms in teacher education curriculum. Unpublished doctoral dissertation, University of DurbanWestville, Durban.

Samoff, R. (1996). Frameworks: An analysis of educational policy document (1995-1996). Paper presented at seminar of the Macro-Education Policy Unit, University of Durban-Westville, Durban, KwaZulu-Natal.

Schneider, M. (1992). Nature and management of specch and hearing problems in a rural area: The role of the community speech and hearing workers. South African Journal of Communication Disorders, 39, 55-61.

Schubert, W.H. (1987). Perspectives, paradigms and possibilities. New York: MacMillan Publishing Co.

Sinclair, M.R. \& Place, J.L. (1991). Changing health in South Africa: Towards new perspective in research. CA, USA: H.J. Kaiser Family Foundation.

Smaling, A. (1992). The pragmatic dimension: Paradigmatic and pragmatic aspects of choosing a qualitative or quantitative method. Research report, University for Humanist Studies, Utrecht, The Netherlands.

Swindler, M.\& Ross, E. (1993). Burnout: A smouldering problem among South African speech language pathologists and audiologists? South African Journal of Communication Disorders, 40, 71-84

Taylor, O.L. \& Clarke, M.A. (1994). Culture and communication disorders: A theoretical framework. Seminars in Speech and Language, 15 ,(2), 103-114.

Uys, I.C. (1993). Kommunikasiepatologie: Onderrig vir die toekoms. South African Journal of Communication Disorders, 40, 3-10.

Van Rensburg, P. (1992). In Committee on Human Resources for Health (1994). Report of the Committee on Human Resources for Health. Ministry of Health, South Africa.

Vaughn-Cooke, F. (1986). The challenge of assessing the language of non-mainstream speakers. In O.L. Taylor. (Ed.). Nature of communication disorders in culturally and linguistically diverse populations. San Diego: College-Hill.

Villanueva, V. (1993). Bootstraps: From an American academic of colour. USA: NCTE. 


\section{INFORMATION FOR CONTRIBUTORS}

The South African Journal of Communication Disorders publishes reports and papers concerned with research, and critically evaluative theoretical and philosophical conceptual issues dealing with aspects of human communication and its disorders, service provision, training and policy.

The South African Journal of Communication Disorders will not accept material which has been published elsewhere or that is currently under review by other publications

\section{MANUSCRIPT STYLE AND REQUIREMENTS}

Manuscripts should be accompanied by a covering letter providing the author's address and telephone numbers. All contributions are required to follow strictly, the style specified in the $P u b$. lication Manual of the American Psychological Assoc. (3rd ed., 1983) (APA Pub. Man.), with complete internal consistency. Four copies of triple-spaced high quality type-written manuscripts with numbered pages, and wide margins should be submitted. They should be accompanied by ONE identical disc copy of the paper. Filenames should include the first author's initials and a clearly identifiable keyword or abbreviation thereof and should be typewritten on the last line of the last page of the Reference List (for retrieval purposes only).

As a rule, contributions should not exceed much more than 30 pages, although longer papers will be accepted if the additional length is warranted. The first page of TWO copies should contain the title of article, name of author(s), and institutional affiliation (or address). In accordance with the APA Pub. Man. style $(1983, p .23)$ authors are NOT required to provide qualifications. In the remaining two copies, the first page should contain only the title. The second page of all copies, should contain only an abstract ( 100 words), written in English and Afrikaans. Afrikaans abstracts will be provided for overseas contributors. Major headings where applicable should be in the order of METHOD, RESULTS, DISCUSSION, CONCLUSION, ACKNOWLEDGEMENTS, REFERENCES. All paragraphs should be indented.

TABLES AND FIGURES which should be prepared on separate sheets (one per page), should be copied for review purposes and only the copies sent initially. Figures, graphs, and line drawings that are used for publication, however, must be originals, in black ink on good quality white paper, but these will not be required until after the author has been notified of the acceptance of the article. Lettering appearing on these should be uniform and professionally done, allowing for a $50 \%$ reduction in printing. On no account should lettering be typewritten on the illustration. Any explanation or legend should appear below it and should not be included in the illustration. The titles of tables, which appear above, the figures, which appear below, should be concise but explanatory. Both should be numbered in Arabic numerals in order of appearance. The number of illustrative materials allowed, will be at the discretion of the Editor (usually about 6).

\section{REFERENCES}

References should be cited in the text by surname of the author and the date, e.g., Van Riper (1971). Where there are more than two authors, after the first occurrence, et al. after the first author will suffice, except for six or more when et al. may be used from the start. The names of all authors should appear in the Reference List, which should be listed in strict alphabetical order in triple spacing at the end of the article. All references should be included in the List, including secondary sources, (APA Pub. Man. 1983, p. 13). Only acceptable abbreviations of journals may be used, (see DSH ABSTRACTS, October; or The World List of Scientific Periodicals). The number of references should not exceed much more than 30 , unless specifically warranted.

\section{EXAMPLES}

Locke, J.L. (1983). Clinical Psychology: The explanation and treatment of speech sound disorders. J. Speech Hear. Disord., 48 339-341.

Penrod, J.P. (1985). Speech discrimination testing. In J. Katz (Ed.), Handbook of clinical audiology (3rd ed.). Baltimore: Williams \& Wilkins.

Davis, G.A. \& Wilcox, M.J. (1985). Adult aphasia rehabilitation: Applied pragmatics. San Diego, CA: College-Hill.

\section{EDITING}

Acceptable manuscripts may be returned to the author for revision. Additional minor changes may also be made at this stage, but a note on the manuscript acknowledging each alteration made by the author is required. The paper is then returned to the editorial committee for final editing for style, clarity and consistency.

\section{REVIEWING SYSTEM}

The peer review of refereeing system is employed as a method of quality control of this publication. Peer reviewers are selected by the editor based on their expertise in the field and each article is sent to two independent reviewers to assess the quality of the manuscript's scientific and technical content. The blind peer review system is employed during which the name of the author/ authors are not disclosed to the reviewers. The editor retains the final responsibility for decisions regarding revision, acceptance or rejection of the manuscript.

REPRINTS: 10 reprints without covers will be provided free of charge.

DEADLINE FOR CONTRIBUTIONS: the preferred date is the 31st May each year, but papers will be accepted until 30th June by arrangement.

QUERIES, CORRESPONDENCE \& MANUSCRIPTS: should be addressed to The Editor, South African Journal of Communication Disorders, South African Speech-Language-Hearing Association, P.O. Box 600, Wits, 2050, South Africa. 


\section{INLIGTING VIR BYDRAERS}

Die Suid-Afrikaanse Tydskrif vir Kommunikasieafwykings publiseer verslae en artikels wat gemoeid is met navorsing, of handel oor krities evaluerende, teoretiese en filosofiese konseptuele kwessies wat oor menslike kommunikasie en kommunikasieafwykings, diensverskaffing, opleiding en beleid gaan.

Die Suid-Afrikaanse Tydskrif vir Kommunikasieafwykings sal nie artikels aanvaar wat reeds elders gepubliseer is, of wat tans deur ander publikasies oorweeg word nie.

\section{MANUSKRIP: STYL EN VEREISTES:}

Manuskripte behoort deur'n dekkingsbrief vergesel te word wat die skrywer se adres en telefoonnommers bevat. Daar word van alle bydraers verwag om die styl, soos gespesifiseer is in die " $\mathrm{Pub}$. lication Manual of the American Psychological Assoc. (3rd ed., 1983) (APA Pub. Man."), nougeset te volg met volledige interne ooreenstemming. Manuskripte moet getik, van hoë gehalte en in drievoud-spasiëring met wye kantlyne wees. Vier kopieë van die manuskrip moet verskaf word. EEN hiervan moet 'n identiese skyfkopie van die artikel wees. Lêername behoort die eerste skrywer se voorletters en 'n duidelike identifiseerbare sleutelwoord of afkorting daarvan in te sluit en moet op die laaste lyn van die bladsy van die verwysingslys getik word (slegs vir naslaan doeleindes).

As 'n reël moet bydraes nie 30 bladsye oorskry nie, maar langer artikels sal aanvaar word indien die addisionele lengte dit regverdig. Op die eerste bladsy van TWEE van die afskrifte moet die titel van die artikel, naam van die skrywer(s), en instansie (of adres) verskyn. In ooreenstemming met die "APA Publ. Man." se styl word daar NIE van skrywers verwag om enige kwalifikasies te verskaf nie. Op die eerste bladsy van die twee oorblywende afskrifte moet slegs die titel van die artikel yerskaf word. Die tweede bladsy van alle afskrifte moet slegs 'n opsom. ming ( 100 woorde) in beide Engels en Afrikaans bevat. Afrikaanse opsommings sal vir buitelandse bydraers voorsien word. Hoofopskrifte moet, waar van toepassing, in die volgende volgorde verskaf word: METODE, RESULTATE, BESPREKINGS, GEVOLGTREKKINGS, ERKENNINGS en VERWYSINGS. Alle paragrawe moet ingekeep;word.

TABELLE EN FIGURE wat op afsonderlike bladsye (een bladsy per tabel/illustrasie) moet verskyn, moet vir referent-doeleindes gekopieer word en slegs die kopieë moet inisieel verskaf word. Figure, grafieke en lyntekeninge wat vir publikasie gebruik word, moet egter oorspronklike weergawes wees en moet in swart ink op wit papier van 'n hoë gehalte wees. Die oorspronklikes sal slegs verlang word nadat die artikel vir publikasies aanvaar is. Letterwerk wat op bogenoemde verskyn, moet eenvormig wees, professioneel gedoen word en daar moet in gedagte gehou word dat dit leesbaar moet wees na 'n 50\% verkleining in drukwerk. Letterwerk by illustrasies moet onder geen omstandighede getik word nie. Verklarings of legendes moet nie in die illustrasie nie, maar daaronder, verskyn. Die opskrifte van tabelle (wat bo-aan verskyn), en die onderskrifte van figure, (wat onderaan verskyn), moet beknop, maar verk larend wees. Numering moet deur middel van Arabiese syfers geskied. Tabelle en figure moet in die volgordè waarin hulle verskyn, genommer word. Die aantal tabelle en illustrasies wat ingesluit word, word deur die Redakteur bepaal (gewoonlik nie meer as 6 nie).

\section{VERWYSINGS}

Verwysings in die teks moet voorsien word van die skrywer se van en die datum, b.v., Van Riper (1971). Wanneer daar egter meer as twee skrywers is moet daar na die eerste verskaffing van al die outeurs, van et al. gebruik gemaak. word. In die geval waar daar egter ses of meer outeurs ter sprake is moet et.al. van die begin af gebruik word. Al die name van die skrywers moet in die Verwysingslys verskyn wat aan die einde van die artikel voorkom. Verwysings moet alfabeties in trippel spasiëring gerangskik word. Al die verwysings moet in die Verwysingslys verskyn, insluitende sekondêre bronne, ("APA Pub. Man." 1983, p.13). Slegs aanvaarbare afkortings van tydskrifte se titels mag gebruik word, (sien "DSH ABSTRACTS, October"; of The World List of Scientific Periodicals). Die aantal verwysings moet nie meer as 30 oorskry nie, tensy dit geregverdig is.

\section{LET OP DIE VOLGENDE VOORBEELDE:}

Locke, J.L. (1983). Clinical psychology: The explanation and treatment of speech sound disorders. J. Speech Hear. Disord., 48, 339-341.

Penrod, J.P. (1985). Speech discrimination testing. In J. Katz (Ed.), Handbook of clinical audiology (3rd ed.). Baltimore: Williams \& Wilkins.

Davis, G.A. \& Wilcox, M.J. (1985), Adult aphasia rehabilitation: Applied pragmatics. San Diego, CA.: CollegeHill.

\section{RESENSERING}

Resensering deur vakkundiges word toegepas as 'n metode van kwaliteitskontrole van hierdie publikasie. Resenseerders word deur die redakteur geselekteer op grond van hulle spesialiskennis en elke artikel word na twee onafhanklike resenseerders gestuur om die kwaliteit van die manuskrip se wetenskaplike en tegniese inhoud te beoordeel. Die naam van die outeur/outeurs word nie aan die resenseerdęr.bekend gemaak nie. Die redakteur behou die verantwoordelikheid vir die finale beslissings aangaande wysigings, aanvaarding of afkeuring van die manuskrip.

\section{REDIGERING}

Manuskripte wat aanvaar is, mag na die skrywer teruggestuur word vir hersiening. Addisionele kleiner veranderinge mag ook op hierdie stadium aangebring word, maar'n nota ter aanduiding van alle veranderinge wat op die manuskrip voorkom, moet verskaf word. Die artikel word dan aan die redaksionele komitee vir finale redigering van styl, duidelikheid en konsekwentheid teruggestuur.

HERDRUKKE: 10 herdrukke sonder omslae sal gratis aan die outeurs verskaf word:

SLUITINGSDATUMS VIR BYDRAES: Bydraes word verkieslik teen 31 Mei elke jaar verwag, maar artikels sal nog tot 30 Junie vir aanvaarding oorweeg word.

NAVRAE, KORRESPONDENSIE EN MANUSKRIPTE: moet geadresseer word aan Die Redakteur, Die Suid-Afrikaanse Tydskrif vir Kommunikasieafwykings, Die Suid-Afrikaanse Spraak-Taal-Gehoor Vereniging, Posbus 600, Wits 2050, SuidAfrika. 